\title{
SAR Study of a Novel Triene-ansamycin Group Compound, Quinotrierixin, and Related Compounds, as Inhibitors of ER Stress-induced XBP1 Activation
}

\author{
I. Taxonomy, Fermentation, Isolation, Biological Activities and SAR Study \\ Tatsuro Kawamura, Etsu Tashiro, Kohta Yamamoto, Kazutoshi Shindo, Masaya Imoto
}

Received: February 25, 2008 / Accepted: May 19, 2008

(C) Japan Antibiotics Research Association

\begin{abstract}
In the course of screening for an inhibitor of ER stress-induced XBP1 activation, we isolated a new member of the triene-ansamycin group compound, quinotrierixin, from a culture broth of Streptomyces $\mathrm{sp}$. PAE37. Quinotrierixin inhibited thapsigargin-induced XBP1 activation in HeLa cells with an $\mathrm{IC}_{50}$ of $0.067 \mu \mathrm{M}$. We found that other triene-ansamycin group compounds such as demethyltrienomycin A and mycotrienin I also inhibited ER stress-induced XBP1 activation. Moreover, we performed SAR study of twelve triene-ansamycin group compounds. The study showed that $\mathrm{OH}$ group at $\mathrm{C}-13$ was crucial, and $\mathrm{CH}_{3}$ group at $\mathrm{C}-14$ would be important for the XBP1 inhibitory activity.
\end{abstract}

Keywords triene-ansamycin, ER stress, XBP1

\section{Introduction}

In tumor microenvironments adverse conditions such as hypoxia, nutrient deprivation and low $\mathrm{pH}$, solid tumor cells are considered to adapt to ER stress by activating X-box binding protein 1 (XBP1) [1, 2]. Indeed, there is now abundant evidence to suggest that XBP1 is a critical transcriptional regulator of this process and required for tumor survival [3 5]. Therefore, we have been screening for an inhibitor of XBP1 activation because the inhibitor of XBP1 activation would be a new type of anticancer drug.

Recently, we have established a screening system for an inhibitor of ER stress-induced XBP1 activation, in which XBP1 activation can be easily detected as luciferase reporter signals in HeLa/XBP1-luc cells [6]. Using this screening system, we have previously reported on the isolation of a novel compound, trierixin (2), from a culture broth of Streptomyces sp. AC654, as an inhibitor of ER stress-induced XBP1 activation [6]. In continuation of this screening, we found that a culture broth extract of Streptomyces sp. PAE37 inhibited ER stress-induced XBP1 activation and isolated a novel triene-ansamycin group compound, quinotrierixin (1), as an inhibitor of XBP1. Despite of the structural similarity of $\mathbf{1}$ to $\mathbf{2}$, the XBP1 inhibitory activity of $\mathbf{1}$ was about 1/5 compared to that of $\mathbf{2}$ (Table 3). This observation prompted us to perform SAR study to know which functional groups of triene-ansamycin group compounds are required for the inhibitory effects against ER stress-induced XBP1 activation. Because the quinotrierixin-producing strain, Streptomyces sp. PAE37, was found to produce several triene-ansamycin group compounds, we further isolated six triene-ansamycin group compounds including three other novel compounds, demethyltrienomycin A (3), demethyltrienomycin B (4), and demethyltrienomycinol (5) from Streptomyces sp.
M. Imoto (Corresponding author), T. Kawamura, E. Tashiro, K. Yamamoto: Department of Biosciences and Informatics, Faculty of Science and Technology, Keio University, 3-14-1 Hiyoshi, Kohoku-ku, Yokohama 223-8522, Japan,

E-mail: imoto@bio.keio.ac.jp
K. Shindo: Department of Food and Nutrition, Japan Women's University, 2-8-1, Mejirodai, Bunkyo-ku, Tokyo 112-8681, Japan 
PAE37, and prepared four derivatives of triene-ansamycin group compounds for SAR study. Furthermore, we also examined whether the XBP1 inhibitory activities of the twelve triene-ansamycin group compounds could correlate with their tumor cell growth inhibitory activities.

Structure elucidation of $\mathbf{1}, \mathbf{3}, \mathbf{4}$, and 5 will be reported in the accompanying paper [7].

\section{Materials and Methods}

\section{General Experimental Procedures}

Mass spectra were measured with a JEOL JMS-T100LC mass spectrometer. UV spectra were recorded on a Hitachi U-2800 spectrophotometer. ${ }^{1} \mathrm{H}$ - and ${ }^{13} \mathrm{C}-\mathrm{NMR}$ spectra were obtained on a JEOL JNM-AL operating at 300 and 75 $\mathrm{MHz}$, respectively. LC/MS system (Waters Corp., USA) with the photo diode array detector (2996) and mass analyzer (micromass ZQ) was used for analysis and preparation.

\section{Taxonomic Studies}

The producing strain PAE37 was isolated from a soil sample collected in Sugadaira, Nagano prefecture, Japan. The morphological characteristics of the strain PAE37 were determined on yeast-starch agar and glucose-asparagine agar incubated at $27^{\circ} \mathrm{C}$ for 6 days.

\section{Preparation of Triene-ansamycin Derivatives}

1) Quinotrierixin HQ (6)

Quinotrierixin $(1,3.0 \mathrm{mg}, 4.4 \mu \mathrm{mol})$ was dissolved in $\mathrm{MeOH}(1.0 \mathrm{ml})$. Five $\mathrm{mg}$ of $\mathrm{Na}_{2} \mathrm{~S}_{2} \mathrm{O}_{4}$ was added to the solution, and the reaction mixture was stirred for 30 minutes at room temperature. The mixture was filtered, and the filtrate was partitioned with EtOAc/ $\mathrm{H}_{2} \mathrm{O}$ (each $20 \mathrm{ml}$ ). The EtOAc layer was dried over $\mathrm{Na}_{2} \mathrm{SO}_{4}$ and evaporated to dryness to yield quinotrierixin HQ (6) as a colorless powder (2.5 mg, yield 83\%).

\section{2) Trierixin Q (7)}

Trierixin $(2,3.2 \mathrm{mg}, 4.7 \mu \mathrm{mol})$ was dissolved in $2.0 \mathrm{ml}$ of $1.0 \%$ methanolic $\mathrm{FeCl}_{3}$ solution and stirred for 1 hour at room temperature. The reaction mixture was partitioned with EtOAc $/ \mathrm{H}_{2} \mathrm{O}$ (each $20 \mathrm{ml}$ ), and the EtOAc layer was dried over $\mathrm{Na}_{2} \mathrm{SO}_{4}$ and concentrated in vacuo to yield trierixin Q (7) as a red powder (3.1 mg, yield 97\%).

3) 13-Keto-mycotrienin I (8) and 13-Keto-mycotrienin II(9) Mycotrienin I (10,3.0 mg, $4.7 \mu \mathrm{mol})$ was dissolved in $0.5 \mathrm{ml}$ of anhydrous $\mathrm{CH}_{2} \mathrm{Cl}_{2}$, and $4.0 \mathrm{mg}$ of Dess-Martin periodinane (Sigma-Aldrich, Saint Louis, MO) was added to the solution. After stirring for 3 hours at room temperature, the solution was partitioned with EtOAc (10 $\mathrm{ml}$ )/saturated $\mathrm{Na}_{2} \mathrm{~S}_{2} \mathrm{O}_{3}$ aq $(5.0 \mathrm{ml})+$ saturated $\mathrm{NaHCO}_{3}$ aq $(5.0 \mathrm{ml})$. The EtOAc layer was dried over $\mathrm{Na}_{2} \mathrm{SO}_{4}$ and concentrated in vacuo to yield 13-keto-mycotrienin I (8) as a yellow powder $(2.5 \mathrm{mg}$, yield $84 \%)$.

Mycotrienin II $(\mathbf{1 1}, 3.0 \mathrm{mg}, 4.7 \mu \mathrm{mol})$ was treated in the same way, and 13-keto-mycotrienin II (9) was obtained as a colorless powder (2.6 mg, yield $87 \%$ ).

\section{Cell Culture}

Human epithelial adenocarcinoma cell line HeLa and $\mathrm{HeLa} / \mathrm{XBP} 1-\mathrm{luc}$ were cultured in DMEM supplemented with $10 \%$ FBS. HeLa/XBP1-luc cells were generated previously [6].

\section{Luciferase Assay}

As reported previously [6], HeLa/XBP1-luc cells were seeded in 96 -well plates at $2 \times 10^{4}$ cells/well, and then incubated with $0.1 \mu \mathrm{M}$ of thapsigargin together with or without each triene-ansamycin group compound. After 24 hours of incubation, the cells were lysed in Passive lysis buffer (Promega, Madison, MA), and then luciferase activity was measured using the luciferase assay system (Promega) and a luminometer (Wallac, PerkinElmer, Waltham, MA). $\mathrm{IC}_{50}$ values were determined from the dose-response curves of the inhibition of XBP1-luciferase activity when the XBP1-luciferase activity of thapsigargin treatment was defined as $100 \%$.

\section{RT-PCR}

As reported previously [6], HeLa cells were seeded in 12well plates at $5 \times 10^{4}$ cells/well, and then incubated with 0.1 $\mu \mathrm{M}$ of thapsigargin together with or without each trieneansamycin group compound for 8 hours. Subsequently, total RNA was extracted from HeLa cells by using TRIzol reagent (Invitrogen, Carlsbad, CA). Aliquots $2.0 \mu \mathrm{g}$ of total RNA were treated with M-MLV reverse transcriptase (Promega) to produce 1st strand cDNA, which was subjected to PCR with KOD Plus polymerase (TaKaRa, Shiga, Japan) using a pair of primers corresponding to nucleotides 505 525 and 609 629 of XBP1 cDNA. The amplified products were separated by electrophoresis on a $6.0 \%$ polyacrylamide gel and visualized with ethidium bromide staining.

\section{MTT Assay}

HeLa cells were seeded at $2 \times 10^{3}$ cells/well in 96-well plates and cultured overnight. The cells were treated with various concentrations of each triene-ansamycin group compound for 72 hours. Growth was measured by 
formazan formation (detected at $570 \mathrm{~nm}$ ) after treatment of the cells with $0.5 \mathrm{mg} / \mathrm{ml}$ of 3-(4,5-dimethylthiazol-2-yl)2,5-diphenyltetrazolium bromide (MTT) for 4 hours at $37^{\circ} \mathrm{C}$. $\mathrm{IC}_{50}$ values were determined from the dose-response curves of growth inhibition.

\section{Results}

\section{Taxonomy of the Producing Strain}

The substrate mycelia of strain PAE37 developed abundantly, were irregularly branched and did not show fragmentation into coccoid forms or bacillary elements. This strain produced dozen of spore chains which were straight, curved or rarely spiraling, on aerial mycelia. LLdiaminopimelic acid was observed in the whole-cell hydrolysates, indicating that the cell wall is type I. On the basis of these morphological and chemotaxonomic characteristics, strain PAE37 was assigned to the genus Streptomyces.

\section{Fermentation of Streptomyces sp. PAE37}

A thawed suspension of Streptomyces sp. PAE37 was used for inoculation in a 500-ml Erlenmeyer flask containing $100 \mathrm{ml}$ of a seed medium composed of $2.5 \% \mathrm{D}(+)$-glucose, $0.2 \%$ yeast extract, $1.5 \%$ soybean meal and $0.4 \% \mathrm{CaCO}_{3}$. The medium was adjusted to $\mathrm{pH} 7.2$ before sterilization. The culture was incubated at $27^{\circ} \mathrm{C}$ for 2 days on a rotary shaker $(150 \mathrm{rpm})$. Aliquots of this seed culture were added to a 500-ml Erlenmeyer flask containing $100 \mathrm{ml}$ of the same medium. The culture was incubated at $27^{\circ} \mathrm{C}$ for 3 days on a rotary shaker $(150 \mathrm{rpm})$.

\section{Isolation and Purification of Quinotrierixin (1)}

The culture broth (2.0 liters) of Streptomyces sp. PAE37 was centrifuged to separate the mycelial cake and the supernatant. The mycelial cake was stirred successively with $\mathrm{Me}_{2} \mathrm{CO}$ (1.0 liter) for 1 hour and filtrated. The filtrates was concentrated under reduced pressure to remove $\mathrm{Me}_{2} \mathrm{CO}$ and combined with broth supernatant because the XBP1 inhibitory activities of the supernatant and the mycelium

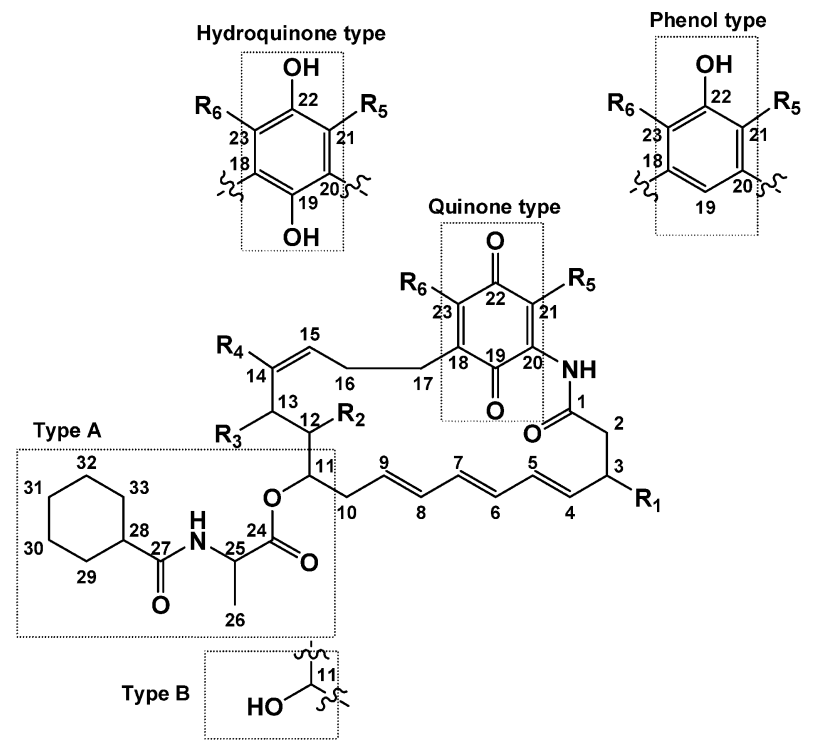

\begin{tabular}{|c|c|c|c|c|c|c|c|c|}
\hline & $\begin{array}{l}\text { Structural } \\
\text { units }\end{array}$ & $\mathbf{R}_{1}$ & $\mathbf{R}_{\mathbf{2}}$ & $\mathbf{R}_{3}$ & $\mathbf{R}_{\mathbf{4}}$ & $\mathbf{R}_{5}$ & $\mathbf{R}_{6}$ & $\begin{array}{c}\text { Side } \\
\text { chain } \\
\text { type }\end{array}$ \\
\hline 1 & Quinone & $\mathrm{OCH}_{3}$ & $\mathrm{CH}_{3}$ & $\mathrm{OH}$ & $\mathrm{CH}_{3}$ & $\mathrm{H}$ & $\mathrm{SCH}_{3}$ & A \\
\hline 2 & Hydroquinone & $\mathrm{OCH}_{3}$ & $\mathrm{CH}_{3}$ & $\mathrm{OH}$ & $\mathrm{CH}_{3}$ & $\mathrm{SCH}_{3}$ & H & A \\
\hline 3 & Phenol & $\mathrm{OCH}_{3}$ & $\mathrm{CH}_{3}$ & $\mathrm{OH}$ & $\mathbf{H}$ & $\mathbf{H}$ & $\mathbf{H}$ & A \\
\hline 4 & Phenol & $\mathrm{OH}$ & $\mathbf{H}$ & $\mathrm{OH}$ & $\mathrm{CH}_{3}$ & $\mathbf{H}$ & $\mathbf{H}$ & A \\
\hline 5 & Phenol & $\mathrm{OH}$ & $\mathbf{H}$ & $\mathrm{OH}$ & $\mathrm{CH}_{3}$ & $\mathbf{H}$ & $\mathbf{H}$ & B \\
\hline 6 & Hydroquinone & $\mathrm{OCH}_{3}$ & $\mathrm{CH}_{3}$ & $\mathrm{OH}$ & $\mathrm{CH}_{3}$ & H & $\mathrm{SCH}_{3}$ & A \\
\hline 7 & Quinone & $\mathrm{OCH}_{3}$ & $\mathrm{CH}_{3}$ & $\mathrm{OH}$ & $\mathrm{CH}_{3}$ & $\mathrm{SCH}_{3}$ & $\mathbf{H}$ & A \\
\hline 8 & Quinone & $\mathrm{OCH}_{3}$ & $\mathrm{CH}_{3}$ & $=0$ & $\mathrm{CH}_{3}$ & $\mathbf{H}$ & $\mathbf{H}$ & A \\
\hline 9 & Hydroquinone & $\mathrm{OCH}_{3}$ & $\mathrm{CH}_{3}$ & $=0$ & $\mathrm{CH}_{3}$ & $\mathbf{H}$ & $\mathbf{H}$ & A \\
\hline 10 & Quinone & $\mathrm{OCH}_{3}$ & $\mathrm{CH}_{3}$ & $\mathrm{OH}$ & $\mathrm{CH}_{3}$ & $\mathbf{H}$ & $\mathbf{H}$ & A \\
\hline 11 & Hydroquinone & $\mathrm{OCH}_{3}$ & $\mathrm{CH}_{3}$ & $\mathrm{OH}$ & $\mathrm{CH}_{3}$ & $\mathbf{H}$ & $\mathbf{H}$ & A \\
\hline 12 & Phenol & $\mathrm{OCH}_{3}$ & $\mathrm{CH}_{3}$ & $\mathrm{OH}$ & $\mathrm{CH}_{3}$ & $\mathbf{H}$ & $\mathbf{H}$ & $\mathbf{A}$ \\
\hline
\end{tabular}

Fig. 1 Structures of triene-ansamycin group compounds. 


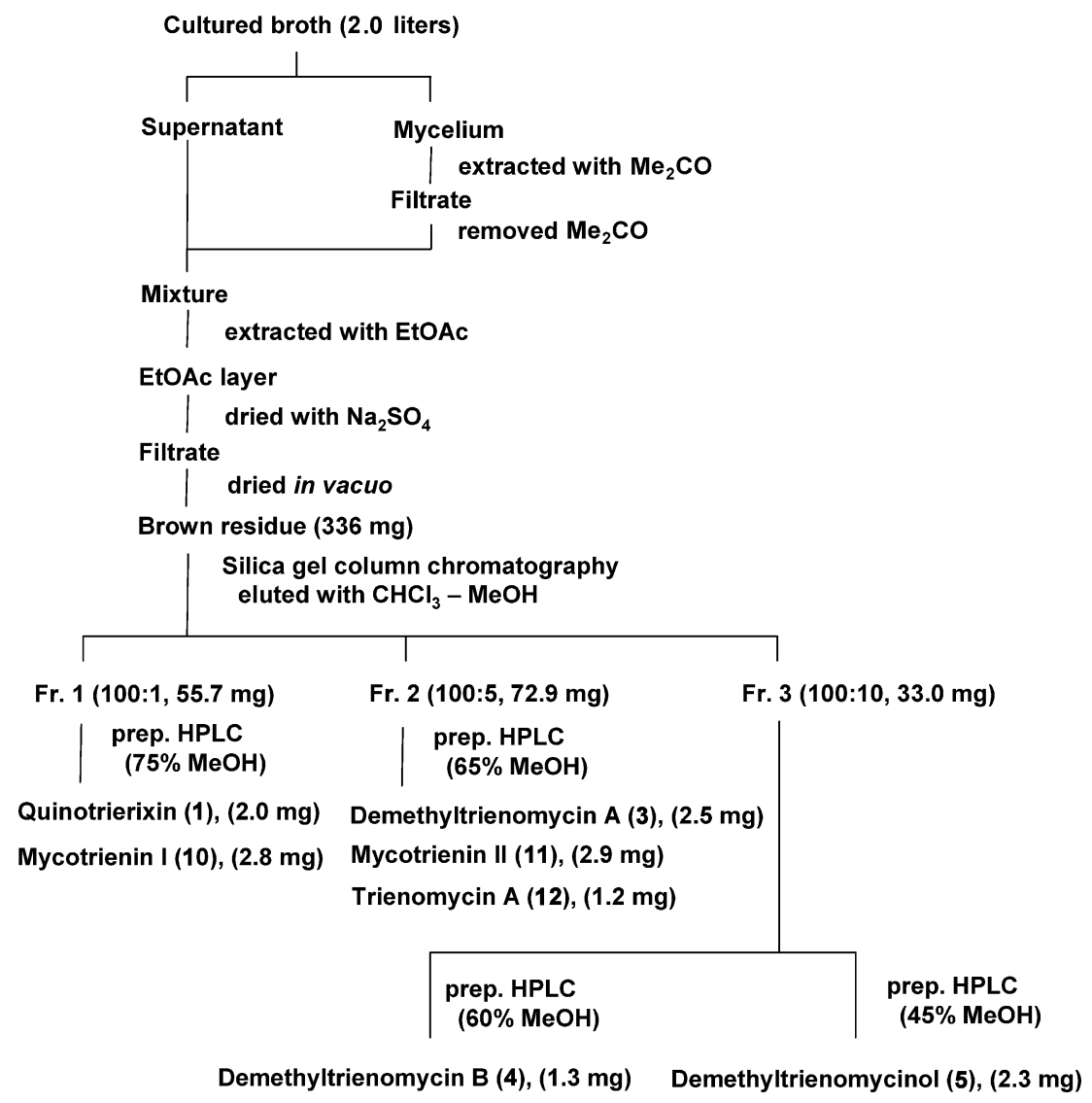

Fig. 2 Isolation procedure of quinotrierixin (1) and related compounds from Streptomyces sp. PAE37.

were in the same range. This solution was extracted with EtOAc (2.0 liters) twice, and the organic layer was concentrated to give an oily residue $(336 \mathrm{mg})$. The crude oil was subjected to silica gel chromatography $(30 \mathrm{~g}$, Silica gel $60,60 \sim 230 \mu \mathrm{m}$, Merck) using $\mathrm{CHCl}_{3}-\mathrm{MeOH}(100: 1)$. The active fractions were collected and further purified by preparative ODS HPLC (Sun Fire, $10 \mu \mathrm{m}, 19 \times 250 \mathrm{~mm}$, Waters Corp., USA) with $75 \%$ aq $\mathrm{MeOH}$ to give pure $\mathbf{1}$ $(2.0 \mathrm{mg})$. The structure, the isolation procedure, the physico-chemical properties and the ${ }^{13} \mathrm{C}-\mathrm{NMR}$ spectral data of 1 were shown in Figs. 1 and 2, Tables 1 and 2, respectively.

\section{Biological Activities of Quinotrierixin (1)}

The inhibitory activity of $\mathbf{1}$ against ER stress-induced XBP1-luciferase activation was first assessed using HeLa/XBP1-luc cells. Treatment of HeLa/XBP1-luc cells with $0.1 \mu \mathrm{M}$ thapsigargin for 24 hours increased XBP1luciferase activities, and $\mathbf{1}$ inhibited thapsigargin-induced activation in a dose-dependent manner with an $\mathrm{IC}_{50}$ value of $0.082 \mu \mathrm{M}$ (Fig. 3). Furthermore, to examine whether $\mathbf{1}$ also inhibited thapsigargin-induced endogenous XBP1 mRNA splicing in HeLa cells, RT-PCR analysis was performed. As described previously [6], treatment with 0.1 $\mu \mathrm{M}$ thapsigargin for 8 hours induced endogenous XBP1 mRNA splicing. $\mathbf{1}$ inhibited thapsigargin-induced endogenous XBP1 mRNA splicing in a dose-dependent manner with an $\mathrm{IC}_{50}$ value of $0.067 \mu \mathrm{M}$ (Fig. 4). These results indicated that $\mathbf{1}$ is an inhibitor of ER stress-induced XBP1 activation.

Isolation and Purification of Six Triene-ansamycin Group Compounds, Including Demethyltrienomycin A (3), Demethyltrienomycin B (4), and Demethyltrienomycinol (5), and Preparation of Four Derivatives of Triene-ansamycin Group Compounds

Recently, we have reported the isolation of trierixin (2), a structurally related compound with quinotrierixin (1), as an inhibitor of ER stress-induced XBP1 activation [6]. The structural differences between $\mathbf{1}$ and $\mathbf{2}$ were the type of a benzenoid moiety (quinone/hydroquinone) and $\mathrm{SCH}_{3}$ position (C-23/C-21). However, the XBP1 inhibitory activity of 1 was about $1 / 5$ compared to that of $\mathbf{2}$ (Table 3 ). Thus, we performed SAR study to know which functional group was required for the inhibitory effects against ER stress-induced XBP1 activation using triene-ansamycin 


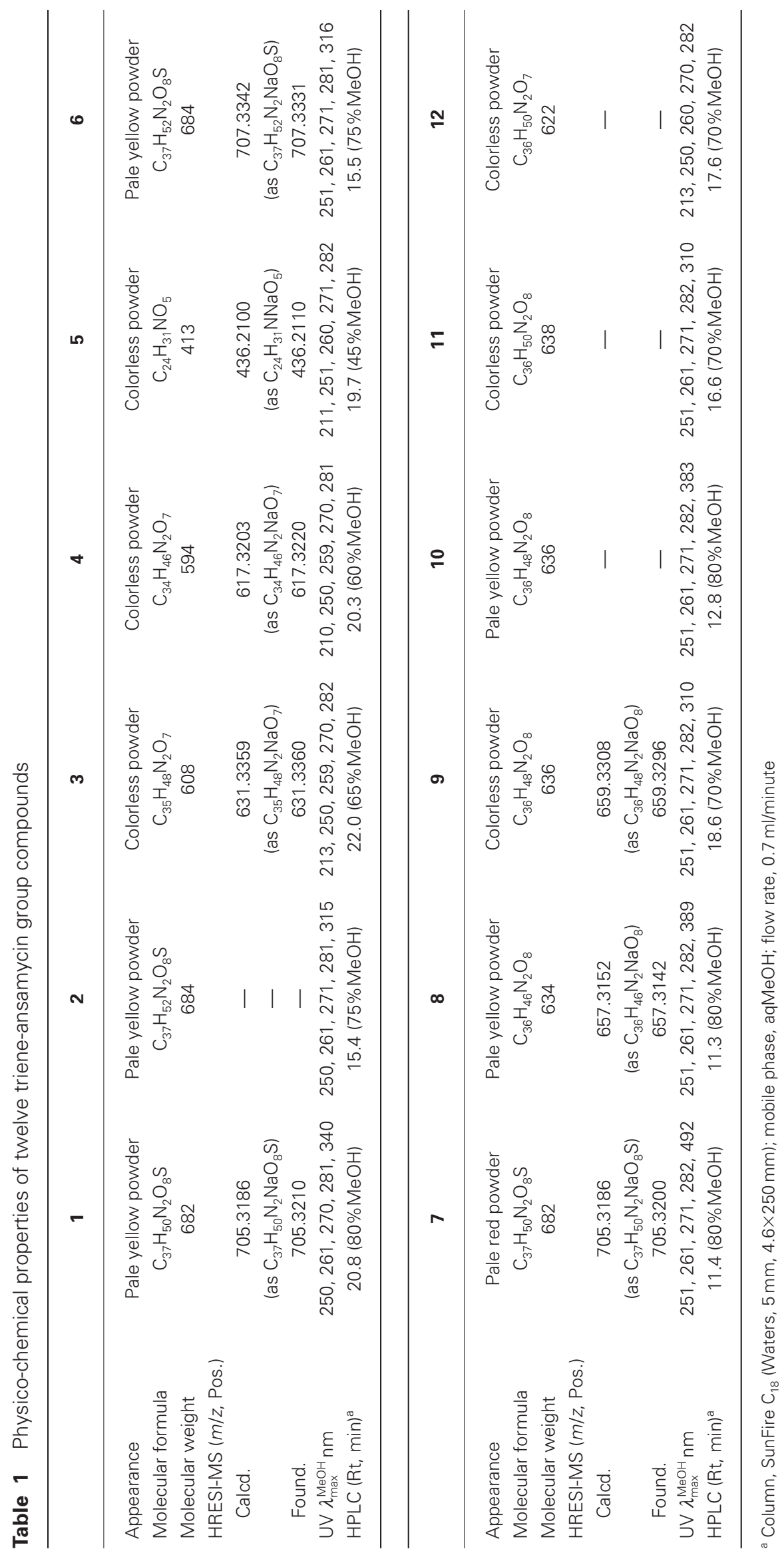


Table $2{ }^{13} \mathrm{C}-\mathrm{NMR}$ assignments of twelve trieneansamycin group compounds

\begin{tabular}{|c|c|c|c|c|c|c|}
\hline Carbon No. & $\mathbf{1}^{\mathrm{a}}$ & $2^{a}$ & $3^{a}$ & $4^{b}$ & $5^{b}$ & $6^{a}$ \\
\hline$C-1$ & 169.4 & 170.8 & 168.6 & 171.0 & 171.3 & 169.9 \\
\hline$C-2$ & 44.7 & 43.5 & 43.3 & 46.6 & 46.6 & 45.0 \\
\hline C-3 & 78.8 & 80.0 & 78.6 & 72.0 & 71.7 & 78.4 \\
\hline C-4 & 130.8 & 129.8 & 129.5 & 135.3 & 134.3 & 129.2 \\
\hline$C-5$ & 133.9 & 135.8 & 133.4 & 132.9 & 132.8 & 134.1 \\
\hline C-6 & 129.3 & 130.3 & 129.4 & 131.3 & 131.0 & 129.3 \\
\hline C-7 & 134.1 & 135.5 & 134.1 & 134.4 & 134.9 & 134.2 \\
\hline C-8 & 133.3 & 134.7 & 133.4 & 134.6 & 134.2 & 133.7 \\
\hline C-9 & 129.8 & 130.4 & 129.4 & 130.0 & 131.6 & 129.6 \\
\hline C-10 & 33.0 & 34.9 & 33.3 & 37.1 & 41.5 & 33.9 \\
\hline$C-11$ & 75.3 & 76.3 & 75.6 & 72.3 & 69.0 & 75.0 \\
\hline C-12 & 38.6 & 39.8 & 40.4 & 39.2 & 41.6 & 39.2 \\
\hline C-13 & 68.5 & 69.4 & 66.5 & 66.9 & 68.2 & 68.6 \\
\hline C-14 & 139.4 & 139.0 & 133.4 & 139.7 & 139.4 & 137.5 \\
\hline$C-15$ & 123.8 & 124.8 & 129.3 & 125.7 & 126.6 & 125.5 \\
\hline C-16 & 26.1 & 27.1 & 34.9 & 29.8 & 30.2 & 27.1 \\
\hline C-17 & 28.8 & 33.2 & 35.7 & 37.0 & 37.3 & 31.9 \\
\hline C-18 & 142.0 & 136.9 & 143.7 & 144.8 & 145.1 & 136.7 \\
\hline C-19 & 178.7 & 143.5 & 111.0 & 114.0 & 113.9 & 141.6 \\
\hline C-20 & 137.7 & 127.1 & 138.1 & 139.8 & 139.8 & 126.9 \\
\hline$C-21$ & 115.8 & 110.9 & 106.2 & 107.8 & 107.8 & 106.0 \\
\hline C-22 & 184.1 & 150.9 & 157.3 & 158.6 & 158.6 & 150.3 \\
\hline C-23 & 147.7 & 116.1 & 111.9 & 112.6 & 112.7 & 119.0 \\
\hline C-24 & 172.9 & 174.1 & 173.0 & 173.9 & - & 172.9 \\
\hline C-25 & 48.5 & 49.5 & 48.5 & 49.7 & - & 48.5 \\
\hline C-26 & 17.7 & 18.8 & 17.8 & 17.2 & - & 18.0 \\
\hline C-27 & 176.5 & 177.4 & 176.5 & 179.1 & - & 176.3 \\
\hline C-28 & 45.0 & 46.0 & 45.0 & 45.8 & - & 45.1 \\
\hline C-29 & 29.4 & 30.4 & 29.4 & 30.4 & - & 29.4 \\
\hline C-30 & 25.6 & 26.6 & 25.6 & 26.6 & - & 25.6 \\
\hline C-31 & 25.6 & 26.6 & 25.7 & 26.8 & - & 25.6 \\
\hline C-32 & 25.6 & 26.7 & 25.6 & 26.6 & - & 25.6 \\
\hline C-33 & 29.4 & 30.5 & 29.4 & 30.8 & - & 29.4 \\
\hline $12-\mathrm{CH}_{3}$ & 10.0 & 10.5 & 9.6 & - & - & 9.7 \\
\hline $14-\mathrm{CH}_{3}$ & 20.4 & 21.2 & - & 18.6 & 19.1 & 19.9 \\
\hline $3-\mathrm{OCH}_{3}$ & 56.7 & 57.6 & 56.8 & - & - & 56.8 \\
\hline $21-\mathrm{SCH}_{3}$ & - & 19.4 & - & - & - & - \\
\hline 23-SCH 3 & 18.0 & - & - & - & - & 19.4 \\
\hline
\end{tabular}

Chemical shifts in ppm from TMS as internal standard

a Recorded at $75 \mathrm{MHz}$ in $\mathrm{CDCl}_{3}$

${ }^{b}$ Recorded at $75 \mathrm{MHz}$ in $\mathrm{CD}_{3} \mathrm{OD}$

group compounds. To perform SAR study of trieneansamycin group compounds, we tried to isolate several triene-ansamycin group compounds from Streptomyces sp. PAE37, and to prepare unnatural derivatives of natural triene-ansamycin group compounds.

Since triene-ansamycin group compounds show the
Table 2 (Continued)

\begin{tabular}{|c|c|c|c|c|c|c|}
\hline Carbon No. & $7^{a}$ & $8^{a}$ & $\mathbf{9}^{\mathrm{b}}$ & $10^{\mathrm{a}}$ & $11^{a}$ & $12^{\mathrm{a}}$ \\
\hline$C-1$ & 167.3 & 169.3 & 171.7 & 169.7 & 169.7 & 168.5 \\
\hline$C-2$ & 43.1 & 43.9 & 43.5 & 44.8 & 43.1 & 43.5 \\
\hline C-3 & 78.7 & 78.1 & 81.9 & 79.2 & 79.6 & 78.5 \\
\hline C-4 & 129.8 & 130.7 & 131.4 & 131.3 & 129.1 & 130.6 \\
\hline$C-5$ & 134.1 & 134.0 & 136.8 & 133.7 & 134.4 & 133.5 \\
\hline C-6 & 129.4 & 129.8 & 130.0 & 129.5 & 129.5 & 129.3 \\
\hline C-7 & 134.5 & 133.3 & 135.7 & 133.7 & 134.9 & 134.1 \\
\hline C-8 & 133.1 & 133.2 & 135.0 & 133.2 & 133.9 & 133.4 \\
\hline C-9 & 129.4 & 128.5 & 130.8 & 129.3 & 129.6 & 129.4 \\
\hline C-10 & 32.9 & 32.9 & 33.5 & 33.0 & 33.7 & 33.1 \\
\hline C-11 & 75.2 & 73.8 & 77.9 & 75.2 & 75.8 & 75.5 \\
\hline C-12 & 40.0 & 46.9 & 46.6 & 39.9 & 39.0 & 39.6 \\
\hline$C-13$ & 68.0 & 204.9 & 210.4 & 68.0 & 68.7 & 68.4 \\
\hline C-14 & 139.8 & 136.9 & 138.2 & 139.9 & 137.8 & 138.6 \\
\hline C-15 & 127.5 & 135.6 & 138.4 & 122.5 & 124.3 & 124.7 \\
\hline C-16 & 25.6 & 27.8 & 31.0 & 25.6 & 26.6 & 29.3 \\
\hline C-17 & 29.7 & 29.7 & 33.0 & 29.4 & 31.7 & 36.2 \\
\hline C-18 & 136.9 & 138.1 & 132.9 & 137.9 & 132.7 & 144.1 \\
\hline C-19 & 181.0 & 182.7 & 142.4 & 188.2 & 141.1 & 110.8 \\
\hline C-20 & 146.5 & 144.7 & 127.1 & 145.4 & 125.5 & 138.4 \\
\hline C-21 & 136.4 & 114.8 & 108.8 & 114.5 & 107.5 & 105.7 \\
\hline C-22 & 182.5 & 188.0 & 151.0 & 182.5 & 149.2 & 157.2 \\
\hline C-23 & 134.0 & 133.8 & 116.1 & 133.1 & 115.8 & 111.9 \\
\hline C-24 & 173.1 & 172.2 & 173.3 & 172.9 & 173.3 & 172.9 \\
\hline C-25 & 48.6 & 47.8 & 50.1 & 48.5 & 48.7 & 48.5 \\
\hline C-26 & 17.4 & 18.6 & 17.2 & 17.4 & 17.7 & 17.8 \\
\hline C-27 & 176.8 & 175.4 & 179.1 & 176.6 & 176.9 & 176.6 \\
\hline C-28 & 44.9 & 45.2 & 45.9 & 44.9 & 45.1 & 45.1 \\
\hline C-29 & 29.5 & 29.5 & 30.6 & 29.4 & 29.4 & 29.5 \\
\hline C-30 & 25.5 & 25.6 & 26.9 & 25.6 & 25.6 & 25.6 \\
\hline C-31 & 25.6 & 25.7 & 26.8 & 25.5 & 25.6 & 25.5 \\
\hline C-32 & 25.5 & 25.6 & 27.0 & 25.5 & 25.7 & 25.7 \\
\hline C-33 & 29.4 & 29.5 & 30.7 & 29.3 & 29.4 & 29.7 \\
\hline $12-\mathrm{CH}_{3}$ & 9.8 & 11.0 & 13.0 & 9.6 & 9.6 & 9.8 \\
\hline $14-\mathrm{CH}_{3}$ & 20.5 & 21.3 & 21.6 & 20.5 & 20.3 & 20.3 \\
\hline $3-\mathrm{OCH}_{3}$ & 56.7 & 57.0 & 56.7 & 56.6 & 56.6 & 56.8 \\
\hline $21-\mathrm{SCH}_{3}$ & 17.4 & - & - & - & - & - \\
\hline 23-SCH 3 & - & - & - & - & - & - \\
\hline
\end{tabular}

Chemical shifts in ppm from TMS as internal standard

${ }^{\text {a Recorded at }} 75 \mathrm{MHz}$ in $\mathrm{CDCl}_{3}$

${ }^{b}$ Recorded at $75 \mathrm{MHz}$ in $\mathrm{CD}_{3} \mathrm{OD}$

characteristic UV spectra $\left(\lambda_{\max } 260,271\right.$ and $\left.281 \mathrm{~nm}\right)$, we searched triene-ansamycin group compounds in the cultured broth of Streptomyces sp. PAE37 using PDA-LC system irrespective of their bioactivities. As the result, we found three novel triene-ansamycin group compounds demethyltrienomycin A (3), demethyltrienomycin B (4), 


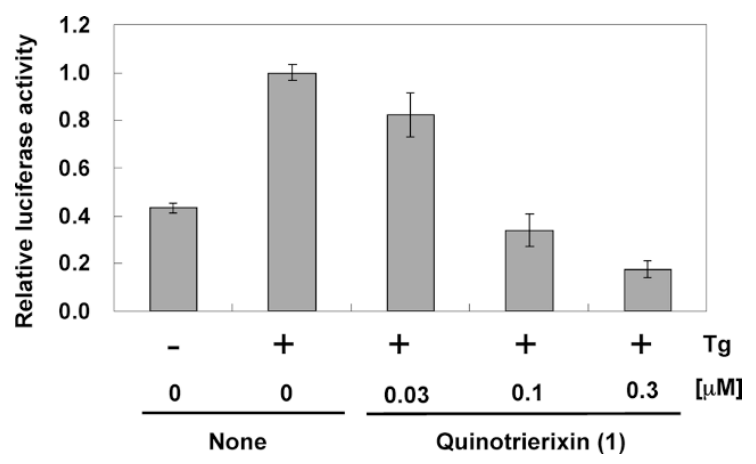

Fig. 3 Quinotrierixin (1) inhibited thapsigargin-induced XBP1 activation.

HeLa/XBP1-luc cells were treated with the indicated concentration of quinotrierixin in the presence or absence of 0.1 $\mu \mathrm{M}$ of thapsigargin ( $\mathrm{Tg}$ ). After 24 hours, the cells were lysed and subjected to luciferase assay. Data are the fold of a thapsigargintreated sample and s.d. of a representative experiment performed in triplicate. and demethyltrienomycinol (5). From 2.0 liters culture, pure $3(2.5 \mathrm{mg}), \mathbf{4}(1.3 \mathrm{mg})$, and $\mathbf{5}(2.3 \mathrm{mg})$ were obtained by using solvent extraction, silica gel column chromatography, and preparative ODS HPLC. Furthermore, in the isolation process of these compounds, mycotrienin I (10), mycotrienin II (11) [8], and trienomycin A (12) [9] were also isolated and identified. The overall purification scheme of these compounds including quinotrierixin (1) was summarized in Fig. 2 .

In addition, we prepared quinotrierixin HQ (6), a hydroquinone derivative of $\mathbf{1}$, and trierixin $\mathrm{Q}(\mathbf{7})$, a quinone derivative of $\mathbf{2}$, to examine the relationship between benzenoid moiety and the XBP1 inhibitory activity. We also prepared 13-ketomycotrienin I (8) and 13ketomycotrienin II (9) to examine the effects of $\mathrm{OH}$ group at $\mathrm{C}-13$ on the XBP1 inhibitory activity. The preparation of $\mathbf{6}, 7,8$, and 9 is described in Materials and Methods. The structure, the physico-chemical properties and the ${ }^{13} \mathrm{C}-\mathrm{NMR}$ spectral data of all triene-ansamycin group compounds were shown in Fig. 1, Tables 1 and 2,
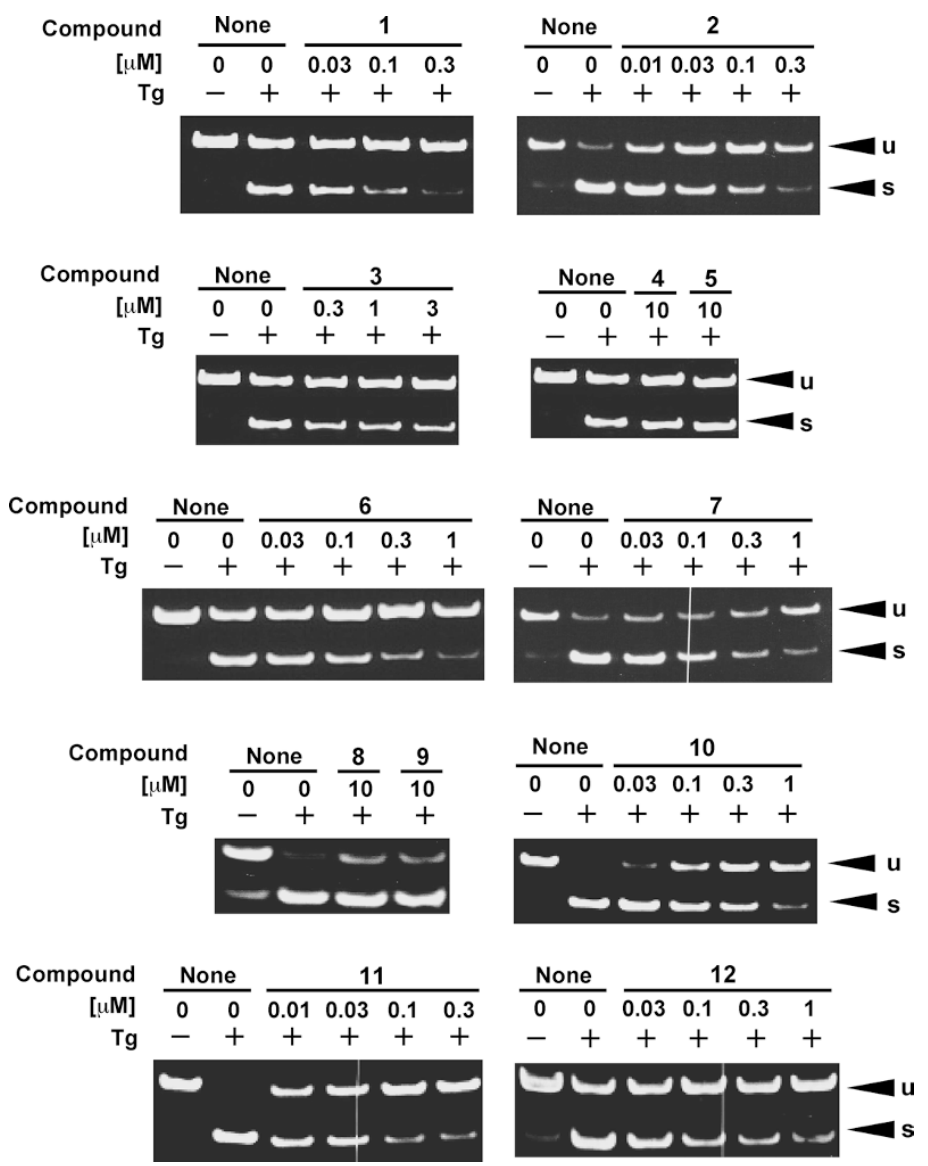

Fig. 4 Triene-ansamycin group compounds inhibited thapsigargin-induced XBP1 mRNA splicing.

HeLa cells were treated with the indicated concentration of triene-ansamycin group compounds in the presence or absence of $0.1 \mu \mathrm{M}$ of thapsigargin (Tg) for 8 hours. The cells were collected and extracted RNA was subjected to RT-PCR. Spliced- or unspliced-XBP1 mRNA was detected as described in Experimental. [s] and [u] indicate spliced and unspliced XBP1 mRNA, respectively. 
respectively.

SAR Study of Twelve Triene-ansamycin Group Compounds as Inhibitors of ER Stress-induced XBP1 Activation

The inhibitory activity of each triene-ansamycin group compound against ER stress-induced XBP1 activation was evaluated by the luciferase assay (Table 3 ) and RT-PCR (Fig. 4). 10 and 11 inhibited both thapsigargin-induced XBP1-luciferase activation (Table 3) and endogenous XBP1 mRNA splicing (Fig. 4) with $\mathrm{IC}_{50}$ of less than $1.0 \mu \mathrm{M}$, respectively, whereas 8 and 9 neither inhibited thapsigargin-induced XBP1-luciferase activation nor endogenous XBP1 mRNA splicing even at $10 \mu \mathrm{M}$. These results indicated that $\mathrm{OH}$ group at $\mathrm{C}-13$ is essential for the XBP1 inhibitory activity. XBP1-luciferase inhibitory activity of $\mathbf{4}$ was reduced to $1 / 500$ of that of $\mathbf{1 2}$, and $\mathbf{4}$ was unable to inhibit thapsigargin-induced endogenous XBP1 mRNA splicing up to $10 \mu \mathrm{M}$, suggesting that $\mathrm{OCH}_{3}$ group at $\mathrm{C}-3$ and $\mathrm{CH}_{3}$ group at $\mathrm{C}-12$ are important for the XBP1 inhibitory activities. The demethylation at $\mathrm{C}-14$ resulted in a reduction of XBP1-luciferase inhibitory activity to $1 / 20$ by comparing 3 and $\mathbf{1 2}$, suggesting that $\mathrm{CH}_{3}$ group at $\mathrm{C}-14$ is also important for the XBP1 inhibitory activity. Although the XBP1-luciferase inhibitory activity of 7 was $1 / 20$ compared to that of $\mathbf{2}$, both $\mathbf{1}$ and $\mathbf{6}$ showed almost the same activities, suggesting that the types of a benzenoid moiety (quinone/hydroquinone) are not so significant for their XBP1 inhibitory activities. Furthermore, by comparing 1, $\mathbf{7}$, and $\mathbf{1 0}$ or $\mathbf{2 , 6}$, and $\mathbf{1 1}$, the following rank orders of XBP1-luciferase inhibitory activities were obtained:

Table 3 Biological activities of twelve triene-ansamycin group compounds

\begin{tabular}{rcc}
\hline Compound & $\begin{array}{c}\text { XBP1-luciferase } \\
\text { inhibition }\end{array}$ & $\begin{array}{c}\text { Cell growth } \\
\text { inhibition }\end{array}$ \\
\hline $\mathbf{1}$ & 0.082 & 0.055 \\
$\mathbf{2}$ & 0.016 & 0.010 \\
$\mathbf{3}$ & 0.40 & 0.86 \\
$\mathbf{4}$ & $>10$ & $>10$ \\
$\mathbf{5}$ & $>10$ & $>10$ \\
$\mathbf{6}$ & 0.078 & 0.20 \\
$\mathbf{7}$ & 0.32 & 0.10 \\
$\mathbf{8}$ & $>10$ & $>10$ \\
$\mathbf{9}$ & $>10$ & $>10$ \\
$\mathbf{1 0}$ & 0.95 & 0.60 \\
$\mathbf{1 1}$ & 0.10 & 0.090 \\
$\mathbf{1 2}$ & 0.019 & 0.029 \\
\hline
\end{tabular}

$I_{50}$ value $(\mu \mathrm{M})$

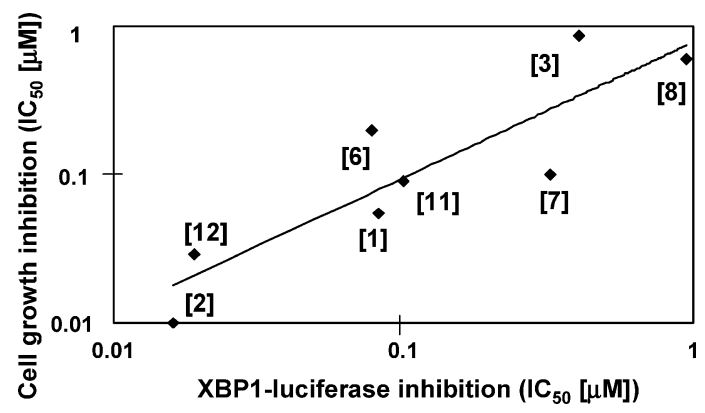

Fig. 5 Correlation between inhibitory activities of trieneansamycin group compounds against XBP1 activation and against tumor cell growth.

The parenthetic numbers indicate the number of compounds.

$\mathbf{1}>7>\mathbf{1 0}$ and $\mathbf{2}>\mathbf{6}>\mathbf{1 1}$. The same results were obtained when the XBP1 inhibitory activity was evaluated by thapsigargin-induced endogenous XBP1 mRNA splicing in HeLa cells (Fig. 4). These results suggested that the presence of a $\mathrm{SCH}_{3}$ group within a benzenoid moiety might be important for showing higher XBP1 inhibitory activity, whereas the position of a $\mathrm{SCH}_{3}$ group is not so crucial for the XBP1 inhibitory activity.

\section{Effects of Twelve Triene-ansamycin Group Compounds on Inhibition of Tumor Cell Growth}

Previously, we showed that 2, 11 and $\mathbf{1 2}$ inhibited not only ER stress-induced XBP1 activation but also tumor cell growth with the subequal $\mathrm{IC}_{50}$ value, respectively [6]. Therefore, we next examined the effects of each trieneansamycin group compound against the cell growth of HeLa cells by MTT assay. As shown in Table 3, most compounds except 4, 5, 8 and 9 , also inhibited cell growth with $\mathrm{IC}_{50}$ value less than $1.0 \mu \mathrm{M}$. Interestingly, there was high correlation between inhibitory effects of trieneansamycin group compounds against XBP1 activation and those against tumor cell growth with the correlation coefficient at $0.71\left(\mathrm{t}_{(6)}=3.51, p<0.05\right)$ (Fig. 5).

\section{Discussion}

Several biological activities of triene-ansamycin group compounds have been reported. Furthermore, the partial structures of triene-ansamycin group compounds that are crucial for their biological activities have also been reported. For example, it has been reported that the acyl chain (cyclohexanecarbonylalanyl moiety) attached at C-11 was crucial for cytotoxicity of mycotrienin I (10) and mycotrienin II (11) against mouse leukemia cells [10]. In addition, trienomycin A (12), which has the acyl chain 
linked at $\mathrm{C}-11$, has more potent inhibitory activity against $\mathrm{NO}$ production in microglia cells than trienomycin $\mathrm{G}$, which has the acyl chain linked at C-13 [11]. On the other hand, it was reported that $\mathrm{OH}$ group at $\mathrm{C}-19$ and the double bonds at C-4, C-6, and C-8 were crucial for the inhibitory activity of mycotrienin II (11) against osteoclastic bone resorption [12]. Furthermore, it has been reported that $\mathrm{OH}$ group at $\mathrm{C}-13$ of trienomycin A (12) was important for its cytocidal activity against $\mathrm{HeLa} \mathrm{S}_{3}$ cells [13], which is consistent with our findings that both 8 and 9 showed only weak their inhibitory activities against cell growth of HeLa cells (Table 3).

There were many reports that triene-ansamycin group compounds showed antitumor effects in vitro and in vivo $[6,14 \sim 16]$, however, underlying mechanisms for the inhibition of tumor growth by these compounds are unclear. In this study, we revealed highly correlation between inhibitory activities of triene-ansamycin group compounds against XBP1 activation and tumor cell growth. These results raised the possibility that the antitumor activities of triene-ansamycin group compounds would be due to the inhibitory effects against XBP1 activation. These findings suggest that this group of compounds may have promise of clinical utility against tumors. The in vitro and in vivo antitumor activity should be explored further in additional to the pharmacokinetics. Also it would be of interest to explore other tumor cells to see if they have alternative pathways for cellular survival under stress.

Acknowledgements We thank Ms. N. Kinoshita (Institute of Microbial Chemistry, Tokyo) for the experiment of taxonomic studies. This study was partly supported by grants from the New Energy and Industrial Technology Development Organization (NEDO) and a grant from Nateglinide Memorial Toyoshima Research and Education Fund of Keio University.

\section{References}

1. Ron D, Walter P. Signal integration in the endoplasmic reticulum unfolded protein response. Nat Rev Mol Cell Biol 8: 519-529 (2007)

2. Moenner M, Pluquet O, Bouchecareilh M, Chevet E. Integrated endoplasmic reticulum stress responses in cancer. Cancer Res 67: 10631-10634 (2007)

3. Romero-Ramirez L, Cao H, Nelson D, Hammond E, Lee AH, Yoshida H, Mori K, Glimcher LH, Denko NC, Giaccia AJ, Le QT, Koong AC. XBP1 is essential for survival under hypoxic conditions and is required for tumor growth. Cancer Res 64: 5943-5947 (2004)

4. Fujimoto T, Onda M, Nagai H, Nagahata T, Ogawa K, Emi M. Upregulation and overexpression of human X-box binding protein $1(\mathrm{hXBP}-1)$ gene in primary breast cancers. Breast Cancer 10: 301-306 (2003)

5. Shuda M, Kondoh N, Imazeki N, Tanaka K, Okada T, Mori K, Hada A, Arai M, Wakatsuki T, Matsubara O, Yamamoto N, Yamamoto M. Activation of the ATF6, XBP1 and grp78 genes in human hepatocellular carcinoma: a possible involvement of the ER stress pathway in hepatocarcinogenesis. J Hepatol 38: 605-614 (38)

6. Tashiro E, Hironiwa N, Kitagawa M, Futamura Y, Suzuki S, Nishio M, Imoto M. Trierixin, a novel inhibitor of ER stress-induced XBP1 activation from Streptomyces sp. I. Taxonomy, fermentation, isolation and biological activities. J Antibiot 60: 547-553 (2007)

7. Kawamura T, Tashiro E, Shindo K, Imoto M. SAR study of a novel triene-ansamycin group compound, quinotrierixin, and related compounds, as inhibitors of ER stress-induced XBP1 activation. II. Structure elucidation. J Antibiot 61: 312-317 (2008)

8. Sugita M, Natori Y, Sasaki T, Furihata K, Shimazu A, Seto H, Otake N. Studies on mycotrienin antibiotics, a novel class of ansamycins. I. Taxonomy, fermentation, isolation and properties of mycotrienins I and II. J Antibiot 35: 1460-1466 (1982)

9. Umezawa I, Funayama S, Okada K, Iwasaki K, Satoh J, Masuda K, Komiyama K. Studies on a novel cytocidal antibiotic, trienomycin A. Taxonomy, fermentation, isolation, and physico-chemical and biological characteristics. J Antibiot 38: 699-705 (1985)

10. Sugita M, Natori Y, Sueda N, Furihata K, Seto H, Otake N. Studies on mycotrienin antibiotics, a novel class of ansamycins. III. The isolation, characterization and structures of mycotrienols I and II. J Antibiot 35: 1474-1479 (1982)

11. Kim WG, Song NK, Yoo ID. Trienomycin G, a new inhibitor of nitric oxide production in microglia cells, from Streptomyces sp. 91614. J Antibiot 55: 204-207 (2002)

12. Feuerbach D, Waelchli R, Fehr T, Feyen JH. Mycotrienins. A new class of potent inhibitors of osteoclastic bone resorption. J Biol Chem 270: 25949-25955 (1995)

13. Funayama S, Anraku Y, Mita A, Yang ZB, Shibata K, Komiyama K, Umezawa I, Omura S. Structure-activity relationship of a novel antitumor ansamycin antibiotic trienomycin A and related compounds. J Antibiot 41: 1223-1230 (1988)

14. Watabe M, Kakeya H, Onose R, Osada H. Activation of $\mathrm{MST} / \mathrm{Krs}$ and c-Jun $N$-terminal kinases by different signaling pathways during cytotrienin A-induced apoptosis. J Biol Chem 275: 8766-8771 (2000)

15. Nishio M, Kohno J, Sakurai M, Suzuki SI, Okada N, Kawano K, Komatsubara S. TMC-135A and B, new trieneansamycins, produced by Streptomyces sp. J Antibiot 53: 724-727 (2000)

16. Hosokawa N, Naganawa H, Iinuma H, Hamada M, Takeuchi T, Kanbe T, Hori M. Thiazinotrienomycins, new ansamycin group antibiotics. J Antibiot 48: 471-478 (1995) 